\title{
Report of the Electric Furnace Committee of the Joint Research Society of ISIJ
}

\section{Heishiro MORIKawa}

\section{1. 概要}

電気灯部会は往米棐鋼部会の下部機满として活動して きた電気灯分科会が㥸和 47 年 10 月に昇恪し, 独立設圆 されたもので，符 1 分科会，第 2 分科会の 2 分科会によ り莡成されている. 第 1 分科会は打もに普通錩を量産し ている $30 \mathrm{t}$ 以上の電気炉をもつ会社の事業所, 旌 2 分 科会は打もに特殊銅を量産している $30 \mathrm{t}$ 以上の雪気炉 をもつ会社の事業所に加盟の资格が与えられる.

現在の会員会社は表 1 亿示される様に第1 分科会が 14 社 18 事業所, 符 2 分科会が 23 社 32 事業所となつて いる. 当部会で取上げられるテーマの内容に電気炉裴铜

表 1 電気炉部会会員会社

\begin{tabular}{|c|c|c|c|}
\hline & 第一分科会 & & 䈞二分科会 \\
\hline $\begin{array}{l}3 \\
4 \\
5 \\
6 \\
7 \\
8 \\
9\end{array}$ & 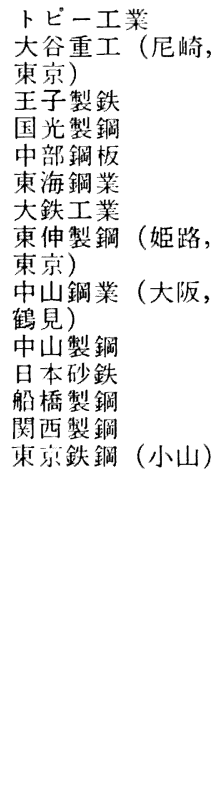 & $\begin{array}{l}14 \\
15 \\
16 \\
17 \\
18 \\
19 \\
20 \\
21 \\
22 \\
23\end{array}$ & 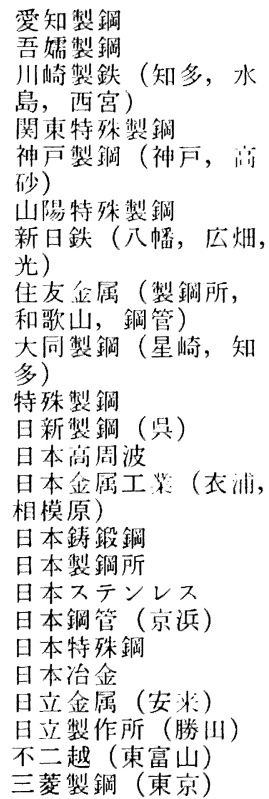 \\
\hline
\end{tabular}

技術に閶与る事で

（1）電父炉の没优，原料，造塊，環境保全，分析な どに関するもの.

（2）华気灿工場の自動化，機械化などに関与ること.

(3) 電気灯淮解に打ける新技術に關すること.

(UHP 操業, 僈元ペレットなど)

(4) その他

となつている．な打第 2 電気炏分科会上ほとんよ゙同じ会 具会社が扣盟している特殊銅部会では電気炉部会とテー マ内容が多少重複する所はあるが，书もに特殊鋼の品篗 を重点に打く㥞一忘区分されている。両分科会の運営方 針はまず現場技術を中心以採り上げ，この会が技術者の 直面する悩み，問題点を卒直に語り合い解決して引く場 にすることを基本理急として符 1 分科会は大谷重工，卜 ピ-工業，東伸製鋼，日本砂鉄鋼業の 4 社，笌， 2 分科会 は日本製鋼所，大同製銅，三望製鋼，䉼日鉄，住友金属， 神戸製銅，日本金属工業の７社が幹事会社となり，(必要

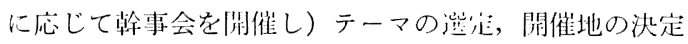
や運営方法を協識しそれそれの分科会の運営に当たつて いる。両分科会とも年 2 回, 春と秋に阙催され，ての打 もな内容は次のと抢りである.

（1）時節に適応した特别苝演，(2) 共通テーマ，及 び自由テーマの各社の研究発表及び質疑灾答, （3）外 国交献の紹介，(4)開催地会社の工場見学，（5)愁視会

なお必要に応じて特定問题を梌討堂詰好るた奻小委員 会を設置するここもある. 又両分科会の交流として，年 1 回は合同幹事会を阙催し，意見，情盛の交換を行ない， 打互いに参考となる研究に他分科会にも発表するように している. 最近の共通テーマの倾向として時節柄環㑽保 全, 省エネルギー, 省資源, 省力化あるいは廃㚞物処理 なぞに集中しているのが特徵である。

以上华父炉部会の枇要を述べたが，当部会は冒副に述 べたように他部会に比べてまだ歴史も㳀く，洒分科会と も6,7回阙催されたに過ぎず，必ずしも部会設置主旨 に沿つた成果をみるに至つていない点はやむを得ないこ 上であり，今後各委員会社の協力により，電気灯の製鋼

\footnotetext{
*日本鉄鋼協会共同研究会電気炬部会部会長 (怢)日本製鋼所本社臨時企画室長
} 
技術向上に寄与し，有意我な成果が期待されるものと考 えている.

\section{2. 分科会の開催地, 議題一臨}

\section{$2 \cdot 1$ 第 1 分科会}

彩 1 回トピー工業 (48 年 2 月, 豊憍)

(1) 特別满演 原子力発電の現状上問題点について 中部電力原子力室部長 湯川氏

（2）電気炉操業上の問題点とその対策 (原料, 電極, 耐火物)

(3) Design and development trends for arc furnaces (Iron Steel June 1971)

第２回 中山製鋼（48 年 10 月，大阪）

(1) 特別临演 UHP 電㥛の課題 炭素協会電極専 門部会長 堤 清和氏

（2）環境保全について（集歴装置, 踽音防止, 夕大 卜，八口造塊阪処理，現場環境改善に闒する問 䫄)

(3) 省力設熥について

(4) Electric melt shop economics (J. Metals, Nov, 1972)

第3 回大谷重工 (49 年 4 月, 川猗)

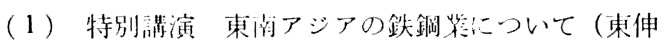
製鋼, 製鋼部長 有働 功氏)

（2）連続鋳造江ついて（設㑴, 操業一般, 品質)

（3）省エネルギー刘箱:つつて (電力制限等)

(4) Electric furnace power system (Iron Steel

Eng., Mar. 1973)

第４回 中山鋼業（49 年 10 月，大阪）

(1) 特別满演 70 トンUHP 電気炉に打ける僈元鉄 の連続装入について一大同製鋼，技術部次長 牛山博美氏

（2）主原料について（配合上品質，操鄴上におよほ 寸問题点，集黁材への影留）

(3) 省力

(4) Utilization SL/RN reduced pellets in electric arc furnaces (Elect. Furn. proc, Vol 25, 1967)

第 5 回 東伸製銅（50 年 6 月，姬路）

（1）特別請演 アーク炻計筫機トータル制御システ ムについて 束芝工業電熱部主務 三国幸宏氏

（2）耐火物扣打る最近の問题例（最近のコスト低 減例，ホットスボット対策）

(3) Air pollution control for an electric furnace melt shop (Iron Steel Eng., May 1974)

激 6 回 東海銅業（50 年 11 月，若松）

（1）特別講演電気炉廃率物の処理について 日本 磁力選鉱鉄鋼本部長 谷川一明氏

（2）電気炉設備および作業の省力化について
(3) 電気炉廃辚物について

(4) Oxygen-assisted electric are furnace operation (Ironmaking Steelmaking, 1974 No. 4)

\section{2 第 2 分科会}

第 1 回 私”会馆（47 年 11 月，東京）

（1）電父炉工場の設保, 生原量, 鋼種, 操業方法の 堪要

（2）設偳，人員，原料，生座，公吉など電気灯作業 に関する問題点

第２回 日本笠鋼所（48 年 5 月，室蘭）

（1）環境保全一集塵装置及びその問題点，造塊場に おけるダスト, ノ口, 煉瓦屑などの集積, 処理 方法, 騒音対策

第， 3 回 大同製鋼（48 年 11 月，名古屋）

(1) 特別講演 鉄くず需給等と対策 日本鉄鋼連盟 原料部 矢部丈夫氏

（2）環境保全について

(3) 省力化について

第 4 回 新日鉄，山陽特殊鎆（49 年 4 月，姫路）

（1）特別满演電気炉の最近の動向と直面寸る課題 石川易播磨重工製鋼プラント設計部 安川昭造 氏

（2）省エネルギー，省資源刘箖

(3) 省力化について

第5 回 日本銅管，日本治金（49 年 12 月，京浜）

（1）省資源，省エネルギー対策及び省力化について

。電気忓工程の短縮（炉外精鋉も含む）

。造塊作業の合理化, 集塵, ダストなどの処理及び 有効利用

。灯前-分析間の合理化

第 6 回 日本高周波，不二戈些，日本ステンレス (50 年 6 月, 富山, 直江津)

（1）省资源，省エネルギー対策及び省力化について 符７四住友金属，川崎彆鉄（50 年 11 月，大阪，西 八宮)

(1) 特別满演

。需気炉の将来（電気炉の構造上の指向について） 大同製鋼 設計部長 江口 勇氏

。東伸製鋼電気灯の高能率操業について 東伸製鋼 姫路製龬所 製鋼部長 有働 功氏

（2）最近の電気炉の耐火物について

（3）電気炉及び付带設備の Maintenance につい $\tau$

（4）減産化における電気炉作棠の Cost 低減例につ w.

（5）廃充物の处理について

\section{3. 最近の発表例}

\section{1 産業廃萐物}

製銅工場から発生する産業廃杗物は，スラグ，ダスト， 


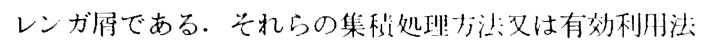
が発表されている。これらの廃军物は, 最近の公暃規制, 作業環境改善の立場から，还来のように投策処理に賴ら ず，再利用するのが就も望ましい状態である。しかし，

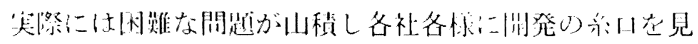
出てう上努力している状態である.

以下，本分科会で発表された例索総合して紹介する。

(1) 酸化スラグについて

酸化スラグの用途としては, 砂利のかわりとして, 路 盤材，コンクリートの骨材や，還元スラグとともに土壤 改良用肥料なよ゙が考えられるが，王子製鉄では，スラグ バラスを路盤材きコンクリートの骨材として利肘するこ とを目的とし，その諸性質を調査している. その結果は 表 2〜4 に示すとおりである. 上記調查の結果, JIS 規 恪のす心゙ての条件を满足していることから, 路盤材はも ちろんのここ，道路のアスフォルト層にも使用できる可 能性があるこ報告している。

\section{表 2 供武材の化学成分}

$(\%)$

\begin{tabular}{c|c|c|c|c|c}
\hline $\mathrm{SiO}_{2}$ & $\mathrm{CaO}$ & $\mathrm{Al}_{2} \mathrm{O}_{3}$ & $\mathrm{FeO}$ & $\mathrm{MgO}$ & $\mathrm{MnO}$ \\
\cline { 1 - 1 } 14.8 & 23.5 & 7.3 & 37.2 & 6.4 & 7.3 \\
\hline
\end{tabular}

(2) 還元スラグについて

還元スラグの再利用は，崩塤する性質在有するため， 骖化スラグ以上に難しい，これについて東伸製鋼では， 2, 3 の筴品の目途がついているが, 経済性に問題があり, 实用化が難しく，製品化の方向づけとしては関係省庁に 债きかける必要があるうと述べている.

(3) ダストについて

ダストは,その主成分が酸化鉄と亜鉛であることから， 粗业捨を回収し，业鉛精錹用の原料として利用されてい

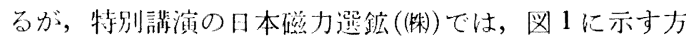
汒によつて粗业鉛の回収を試みている。この方法は，溶 融スラグつまり出棌した直後のスラグ中に，ダストとコ 一クス粉を混合したものを投入し，この時発生する蒸気 やの酸化两鉛をバックフィルターで回収する方法であ る.

李た，東伸製鈰上り，在则路它気炉会社 3 社の協同開発 により，「新会社邚路製銓リフォイン」在設立し，ダスト 処理のための処理工場（処理能力 $10 \mathrm{t} / \mathrm{hr}$ ) として訃画 し, 既に50 年 10 月に着工し, その処理内容が紹介され た.汹 2 はその処理工程を示したものであり,この方法

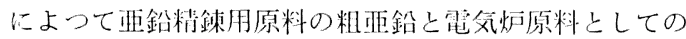
鉄粉を回収することができ，回収物の化学成分は，芘 5 に示すようなものになるこいいている。

表 3 スラグバラスの骨材試験および路盤材試験結果

\begin{tabular}{|c|c|c|c|c|c|c|c|c|c|c|c|}
\hline & & \multicolumn{4}{|c|}{$\begin{array}{l}\text { 比重・眐水量および } \\
\text { 単位容積重量試騟 }\end{array}$} & \multirow{2}{*}{ 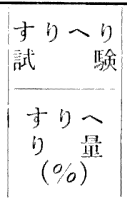 } & \multirow{2}{*}{ 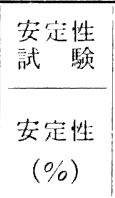 } & \multicolumn{3}{|c|}{ 液性限界 - 飳性限界侙験 } & \multirow{2}{*}{$\begin{array}{l}\text { 修 正 } \\
\text { CBRR } \\
\text { int 影 } \\
\begin{array}{c}\text { 修 正 } \\
\text { CBR 值 } \\
(\%)\end{array}\end{array}$} \\
\hline & & 比 重 & $\begin{array}{c}\text { 吸水量 } \\
(\%)\end{array}$ & $\left|\begin{array}{l}\text { 単位容稍 } \\
\text { 重 } \\
\left(\mathrm{kg} / \mathrm{m}^{3}\right) \\
\text { 量 }\end{array}\right|$ & $\begin{array}{c}\text { 笑綨率 } \\
(\%)\end{array}$ & & & $\mid \begin{array}{c}\mid \text { 液性限界 } \\
(\%)\end{array}$ & $\mid \begin{array}{c}\text { 望性限界 } \\
(\%)\end{array}$ & {$\left[\begin{array}{c}\text { 乷性指数 } \\
(\%)\end{array}\right.$} & \\
\hline \multicolumn{2}{|c|}{ スラグバラス } & 3.884 & 1.003 & 2441 & 62.8 & 16.3 & 1.0 & 20.3 & 20.2 & \multirow{2}{*}{0.1} & \multirow[t]{2}{*}{176} \\
\hline & $\mathrm{B}$ & 3.35 & 2.06 & 1.97 & 58.8 & & & & & & \\
\hline \multirow{2}{*}{ 参 } & JISA 50011 種 & 2.45以上 & 3.0 以下 & & & 35以下 & (12以下) & & & \multirow{3}{*}{$\begin{array}{l}\text { (4以上) } \\
\text { (4以上) }\end{array}$} & \multirow{2}{*}{$\begin{array}{l}(80 \mathrm{~L} \text { 上 }) \\
(80 \text { 以上 })\end{array}$} \\
\hline & 道路用砕石 2 種 & & & & & 40以下 & (20以下) & & & & \\
\hline \multirow[b]{2}{*}{ 考 } & JISA 5005 & & & & & & & & & & \\
\hline & $\begin{array}{r}\text { コンクリート用 } \\
\text { 砕价 }\end{array}$ & 2.5 以上 & 3.0 以下 & & & 40以下 & 12以下 & & & & \\
\hline
\end{tabular}

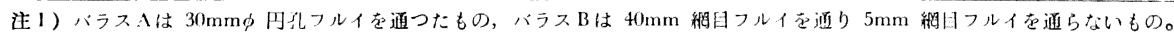
2)（）内は規椔值ではなく望ましい值である。

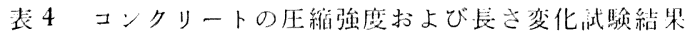

\begin{tabular}{|c|c|c|c|c|c|c|c|c|c|}
\hline & \multicolumn{4}{|c|}{ 配合量 $\left(\mathrm{kg} / \mathrm{m}^{3}\right)$} & \multicolumn{2}{|c|}{$\begin{array}{c}\text { 压縮強度㖶騃 } \\
\left(\mathrm{kg} / \mathrm{cm}^{2}\right)\end{array}$} & \multicolumn{3}{|c|}{$\begin{array}{l}\text { 長さ変化試験 } \\
\left(\text { 収箖量 } \times 10^{-4}\right)\end{array}$} \\
\hline & セメント & 水 & 川 仯 & $\begin{array}{l}\text { スラグ } \\
\text { ハラス }\end{array}$ & 1 週 & 4 週 & 1 週 & 4 週 & 13週 \\
\hline スラク゚バラス $\mathrm{B}$ & 295 & 202 & 865 & 1160 & 144 & 247 & 1.35 & 4.21 & 7.33 \\
\hline " & 448 & 179 & 708 & 1314 & 365 & 475 & 1.56 & 3.58 & 5.30 \\
\hline
\end{tabular}

注1）セメントは普通ポルトランドセメントを使用。

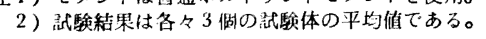


乷粞ししたダトを，鉄鉱不の代換として，電気炉に再 投入する方法を日立金属や日立製作所勝田工場が発表し ている.

\section{2 電炉用耐火物}

最近ひ它気灯の倾向として，生産性向上対策のため，

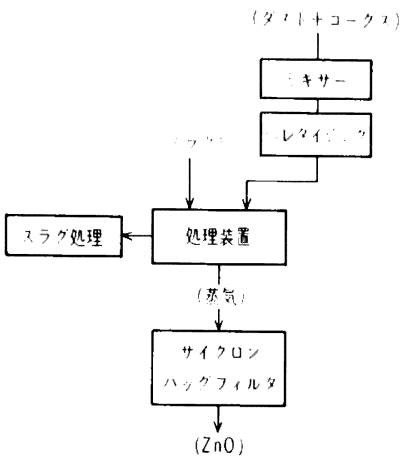

図1日本磁力選䤱 (怢) の粗亜鉛回収方法

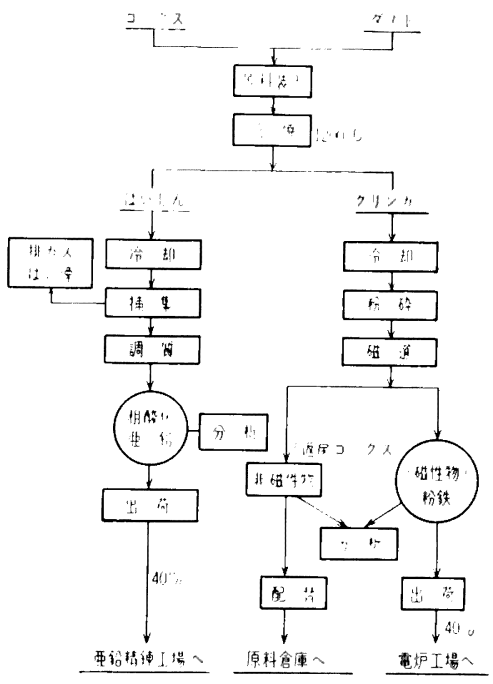

図 2 姫路リフォインによる粗垔鉛と粉鉄の 回収工程
炉容の大型化が進み，それとともに高電力操業, 助燃バ 一ナーの設置, さらに大量の酸素使用がなされ，電気炉 耐火物に与える影響はますます苛酷になつている。

さらに 49 年末以来, 電炉の操短が余儀なくされ, 間 哭操業の悪影響が耐火物原监位の上昇に，なおいつそう の拍車をかけている.

このような悪条件を克服するため，各社方法は異なる が，それぞれ積極的に耐火物原単位の低減に最大限の努 力をはらつている.

(1) 炉壁耐火物について

各社電炉用耐火物の中でも特にホットスポット部の対 策に最も力を入れている. 従来から一般的になされてい る方法としては, 各企業の操業条件にコスト的に最も適 合した耐火物の選定，あるいは張り分け方の追求がある.

これらの一般的な傾向としては，炉壁耐火物はより高 級な耐火物一と变更されつつある. 具体的な報告例とし ては,

。不燃成 $\mathrm{C}-\mathrm{MgO}$ 質を電鋳 $\mathrm{Mg}-\mathrm{Cr}$ 質あるいは超高 温 $\mathrm{Mg}-\mathrm{Cr}$ 質に置換した例（東海鋼業）

。酸素使用量の影響を強くうける $\mathrm{C}-\mathrm{MgO}$ 煉瓦を $\mathrm{Cr}-\mathrm{Mg}$ 煉瓦に変更して効果をあげた例（妕山製鋼）

○ダイレクトボンド煉瓦をカーボン煉瓦と $\mathrm{C}-\mathrm{MgO}$ 煉瓦に変更し, 酸化の問題は使用条件によつて使い 分けて効果をあげた例（大谷東京）

。煉瓦材質のグレードアップ ( $\mathrm{MgO}$ 含有量の増加, 高密度化）によつて効果をあげた例（大谷尼崎）

。高温焼成煉瓦をタール含浸ダイレクトボンドマグド 口煉瓦に变更して効果をあげた例（関西製鋼）

。C-MgO 煉瓦を試用し，中間補修の省略が可能にな つた例 (関東特殊)

。高温燃マグクロボンドを採用した例（日新呉） などがある。

さらにホットスポット部の対策として，最も效果的な 方法である炉壁の水冷化が注目されている.

水冷ボックス，パーマネントブロック，水冷ジャケッ トなど方法はいろいろある. しかしスパーク，直接酸素 の吹付けなどによつて水洩事故が発生し，それによる休 炉もさることながら，安全上にも多くの問題が残されて いる.これら水冷炉壁のなかでは，耐火物を通した間接

装 5 姫路リフォインによる粗正鉛と粉鉄の成分

1) 粗曹鉛

\begin{tabular}{c|c|c|c|c|c|c|c|c}
\hline $\mathrm{Zn}$ & $\mathrm{Pb}$ & $\mathrm{Cd}$ & $\mathrm{Fe}$ & $\mathrm{Mn}$ & $\mathrm{Cl}$ & $\mathrm{S}$ & $\mathrm{F}$ \\
\hline $50 \sim 60$ & $7 \sim 12$ & $0.1 \sim 0.2$ & $1 \sim 2$ & $0.02 \sim 0.1$ & $7 \sim 10$ & $1 \sim 2$ & $0.2 \sim 0.5$ \\
\hline
\end{tabular}

2) 粉 銑

\begin{tabular}{l|c|c|c|c|c|c|c|c|c|c|c}
\hline $\mathrm{T} . \mathrm{Fe}$ & $\mathrm{SiO}_{2}$ & $\mathrm{Al}_{2} \mathrm{O}_{3}$ & $\mathrm{CaO}$ & $\mathrm{MgO}$ & $\mathrm{Zn}$ & $\mathrm{Pb}$ & $\mathrm{Cr}$ & $\mathrm{Cu}$ & $\mathrm{C}$ & $\mathrm{P}$ & $\mathrm{S}$ \\
\hline $50 \sim 53$ & $8 \sim 12$ & $6 \sim 8$ & $8 \sim 10$ & $4 \sim 7$ & $<1$ & $<1$ & $0.1 \sim 0.3$ & $0.4 \sim 0.5$ & $1 \sim 3$ & $0.1 \sim 0.3$ & $1 \sim 2$ \\
\hline
\end{tabular}


的な水冷方式がコスト, 耐久性, 安全性の面で有望視さ れており，報告例も多かつた。 しかしこれについても各 社使用実績が浅く, 今後特性の把握, 最適例用方法の確 立が急務であろう。

具体的な報告例としては

。フラットバー付水冷ボックスを使用し水洩事故を皆 無にして交換ピッチを 3 カ月から 6 力月以上とした 例 (日本砂鉄)

。水冷ジャケットとカーボン煉瓦を結びつけたパネル 型水冷ジャケット方式パーマネントブロック效别を 上げた例（東伸 東京）

。パーマブロックは 700〜1000チャージで水冷ハイ プの露胡が見られる. しかしその後も伐用可能で， 探算点の 950 回をはるかに越えた耐用回数を示した 例 (中山製鋼)

○パーマブロックの耐用回数は $1000 \mathrm{ch}$ 以上で水冷 ボックスに比べ安全性, 経済性で有利であつた例 (トピー工業)

○炉壁天端ならびにホットスボット部に水冷ボックス を取付け，さらに位置変更をして効果をあげた例 (大鉄工業)

。水冷ボックスの採用之熱間吹付補修の実施で寿价延 長を行なつた（住友金属製鋼所）

などがある。

(2) 天井耐火物について

HP 化に伴うホットスボット部の溶損, 大星酸素使用 による集塺孔，電極孔部の溶損など，天井耐火物につい

ても，従来より赫酷な条件を要求されている.

一般的な傾向として従来の珪石質から，より耐火度の 高、塩基性質へと变更されつつある。しかし㙁基性質は 珪石質に比べ溶損は少ないが，熱膨張による天井アーチ の変形, 炉の間歇操業によるスポーリング損失によつて, 思つたほどの効果をあげていないのが現状である。

それら珪不，塩基性の中間的な性斦をもつた高アルミ ナ質もラミング材として，あるいは煉瓦として使用し効 果をあげている.

只体的な報告例としては

。熱変動の影響をうけにくい高アルミナ天井を使用 し，比較的良い成績を収めた例（日本砂鉄）

。集鷹孔りング，小天井ラミング材の材質アップおよ び利離の激しい部分の煉瓦寸辰の增加とゼブラ方式 化で良好な結果が得られた例(束海銅業)

。電極孔，集㕍孔を不定形からスリーブ煉瓦に変更， 集㦄孔径の增加, ドーム径を減少させて耐用回数を 增加させた例（東伸 東京）

。塩基性天井の変形防止を目的にホットスポット部を 空冷して効喿をあげ，さらに修理サイクルの変更に よつて原単位を向上させた例（大谷 東京）

。オール珪石煉瓦とスタンプ珪不煉瓦の耐用の比較,
および塭基性煉瓦十スタンプ材天井の試用結果の報 告例（国光製銅）

。ステンレス溶製炉で $\mathrm{MgO}$ 成分を変化させ耐熱スボ ール性を改善した例（川鉄西宮）

。小天井に不焼成八イアルミナ定形煉瓦十スタンプ材 を採用した例（日新製鋼呉）

。出鋼から次の通電までの㭙問の長短によつてハイア

ル之，䞍不壳使い分けていく例（日本金属工業） などがある。

(3) 忺鋼桶耐火物について

出鋼樋については，良来ブロック組立法が通常であつ たが，最近は一体化されたものが市吸されている。材啠 在检討した発表例として，

。ジルコン啠ラミング材の替りに，アルミナ炭珪質レ ンガを使用し，修理時の作業性を泉好にした例（川 鉄・西宮)

○ジルコン炭珪㙄一体型と\%囟，コストともに所期の 日的を这寸ることができた例（日立金属安来）

。力ーボン侵入防止上目地溶損防止を考惫して，高ア ルミナの不烧成一体式を使用し104回の实績芯示し た例（住友金属・罁管整造所）

などがある。

\section{3 還元鉄の使用}

我国における鉄佰の供給の不安定と俩格の変動は，電 父师メ一カーにとつては，大きな問題であり，抜本的な 原料対策に迫られて，供給が比較的安定している還元鉄 に改めて関心が払われてきた。

しかしながら，我国の電父炣メーカーに抢いて還元鉄 优用の实績が少なく，その技術的評俩の检討を早急に行 なう必要性があつた。このような背景のもとに, SL/RN 法又は MIDREX 法などによつて製造された還元鉄が 日本の各電父炉メ一カーに供給され，その栣値它技術面， 経済面を惻討する機会に恵まれた。

電父小部会に発表された報告を以下に要約する.

(1) $\mathrm{SL} / \mathrm{RN}$ 法の還元鉄配合率 30〜40\% になるよ うに連続装入し，70 トン UHP 灯での可能性 を追求した。（大同製鋼）

（2） MIDREX 法の還元鉄を配合率 40\% まで， $3.3 \%$ 刻みにバスケット装入で行な，50t 䨨 灯で溶解した例（船橋製鋼）

（3） MIDREX 泛の高元鉄它限合率 $40 \%$ まで， バスケット装入で行ない, $70 \mathrm{t}$ 雪炕で溶解した 例（大同製鋼 知多）

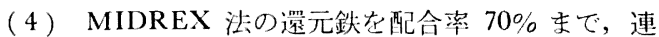
続文はバスケット装入て，40 t 電炉で溶解した 例（日新製鋼 只）

（5）MIDREX 法の還元鉄を配合率 50\% まで，三 とおりの装入法で行ない，120 t 奄炕で溶解し た例（月本製鋼所 莳蘭） 
（6） MIDREX 法の還元鉄を配合率 $53 \%$ まで，バ スケット装入で行ない, $40 \mathrm{t}$ 電灿で溶解した例 (三菱製鋼 束京)

これら各社の試験の結果, 共通する点は,

（1）华力原単位が全鉄用装入に比べて上つている.

（2）溶解時間も全鉄㞛装入に比べて長くなる.

（3）還元鉄の配合率が 30\% 以下ならば，支踤なく 操業可能であるが，50〜60\% 程度になると突沸 の危険性がでてくる.

（4）還元鉄は不純元素 $\mathrm{Cu}, \mathrm{Sn}, \mathrm{As} ， \mathrm{Ni}$ ，は少ない ので，これらの元素を嫌う鋼種の溶解に有効で ある。

（5）製品の品質の良否は，普通法に比較して総じて 問题ないとしている.

\section{4 省力化}

電気炉作業は一般的に高溫, 重筋学働が主体となつて いるので，従来から省力化，自動化が叫ばれてきたが， その実現化はなかなか進安なかつた，しかし最近この分 野にも积㥛的な省力化自動化の動きが強く見受られ，電 父师部会でも数多く省力化設備の紹介がされている. 以 下簢単に代表例在示与。

副原料自動科量投入装置は促来作業員が電気炏製鋼に 使用する副原料を科量し，さらに炉内に投入していたが， これを自動化し，科量投入の操作をワンタッチ方式で完 港させるものである. 作業員 7 名ならげ 1 2 名が減少 できるなら゙不二越東富山をはじめ多数の会社から発表さ れている.

電極を接続する作業は，作業員が炉上の高熱，高所に て敏速に行なう重筋作業であり, 困難な仕事の一つであ る. 大同製鋼では電㥛自動接綂装置を試作し，その利点 として, 従来 2,3 名必要とした作業員が 1 名で足り, 接続々スもなくなり, 安全性も確立されたとしている.

電炉の補修作業は彷来スコップによる投込み法が主で あり，作業性が悪かつた．この点を解消したのが吹付機 である. その勃果として作業員は 5 名が 3 名になり, 補 修のバラツキもなくなり，作業時間も短縮されたょして いる.

電灯の溶解促進を図るた放, 助熱バーナとしてトロイ ダルバーナーの使用が増加してきており, これも省力化 の一環である.

電子計算機を採用し, 電炉と組合せて, 電力原単位の 低下，自動分析化を図つた例を日本製鋼所，さらにスク ラップの科量から出鋼までの一貫プロセスを，各制御装 置てて管理するシステムを吾嬬製鋼仙台が発表している。

\section{4. 近況}

\section{$4 \cdot 1$ 研究発表}

各社事業所とも分科会出席は $2 \sim 3$ 名以内に制限され
ているので, 開催地会社の数名を含めて第 1 電気炉分科 会は 50〜60 名程度, 第 2 電気炉分科会は 80〜90 名程 度となつている. 研究発表会としては第 2 分科会が多少 多すぎることと, 出席会社の性格が広籁囲にわたり色々 異なつているのに反し，第1 分科会の方は 50〜60 名と ちようど手頃の人数であるとともにいわゆる平電炉普通 䤱メ一カーのみの集りであるため, 発表に対する質疑応 答も回を相るるごとに活発化し，幹事も捌きに苦虑する 程で, まさに全員参加の研究会という印象が強く感じら れる. 第 2 分科会の方も早くその様な研究会にもつてゆ きたいと思う. 今後は分科会ともパネルデスカッション 方式を取り入れたり，両分科会の 1 部交流なども行ない ながらより充実したものにしてゆきたいと考えている。

\section{2 工場見学}

見学の対象は電父炋工場が主体となり，灯本体とその 附属設備, 連続鋳造機や作業環境などについて詳細に見 学し, 時には後工程の圧延, 鈑鍊工場など直接関倸しな 、分野の見学も含め，相互の技術水準向上や視野の拡大 に大いに貢献している. 最近の電気炉は設借の大型化, 高電力操業の実施, 種々の自働化装置の採用などにより 生産性の向上が著しい. 又集塺機の完備などによる作業 環境の改善が強く感じられる. しかし不況による減産体 制下の昨今では休止炉も多く見受けられ，工場見学にも 一抹の淋しさがある.

\section{$4 \cdot 3$ 留親会}

両分科会とも回を重视るごとに知已も増え，良い意味 での分科会フォミリーを形成しつつあるように思える. 昼間の研究発表会ではお互にきくことのできなかつた事 項に類することや裏話などが，宴の進行について交換さ れる風景もしばしば見受けられる。この怅な相互関係が 㤾社後の技術情報の交換などにまで発展しているようで ある. 促つて留視会は分科会の日程の1つとして久かす ことのできない理由でもある、こうした懇親会はややも すると華美になりがちであるが，最近はできるだけ質素 のうちに内容のあるものにするよう心がけている.

\section{5.むす び}

以上電気炉部会の最近の活動状況について簡単に御紹 介した。冒頭にも述べた様に当部会は発足してまだ日も 浅いた放確たる成果はあがつていないが，今後各社の協 力を得て運営方法の改善, 内容の充実を計りながら, お 互いの切差域磨之電気炉製鋼技術のより一層の発展の基 盤をつくりあげる様努力したい, 又一方平電炉普通鋼メ 一カーを対象とした第 1 分科会は别として第 2 分科会は ほとんど同一メンバーで構成されて同じょうな分野を取 报つている特殊鋼部会との関連から今後どの様にもつて ゆくかがーつの課題でもある. 